\title{
A Comparative Study of the Miserable Fate of Tess and Xianglin's Wife from Legal System
}

\author{
Haiting Chen \\ Zhejiang Ocean University, Zhoushan, China \\ Jingjing Lu \\ Zhejiang Ocean University, Zhoushan, China
}

\begin{abstract}
Law and Interdisciplinary research ("Law-and") has flourished since the 1960s. "Law and literature" is an academic movement under such a background in the United States. The author uses Tomas Hardy's Tess of the d'Urbervilles and Lu Xun's The New-Year Sacrifice to analyze and compare the legal system in British Victorian and Chinese semi-feudal and semi-colonial society, and explores the root causes of the tragic fate of Tess and Xianglin's Wife. Meanwhile, the paper reveals the predicament of women in the East and West around the 20th century.
\end{abstract}

Index Terms - legal system, law and literature, miserable fate, predicament of women

\section{INTRODUCTION}

\section{A. Theoretical Background}

1. Introduction of "Law and Literature"

"Law and literature" is an academic movement that originated in the United States. Law, as a discipline, has a long history. However, since the 1960s, law as an autonomous discipline has gradually declined in the United stated.(Ponser, 1987) Law and Interdisciplinary research ("Law-and") has flourished, such as law and economics, sociology, political science, feminism, and clan theory. "Law and literature" emerged under such a background. In 1973, James Boyd White, a professor at the University of Chicago Law School, published The Legal Imagination, which marked the beginning of "Law and Literature" in the United States. In the 1980s, "Law and Literature" stood in the United States and spread to other common law countries such as the United Kingdom. This is attributed to Richard Allen Posner, a scholar who has expertise in law, economics, and literature. He has published Law and Literature: A Misunderstood Relation (1988), Overcoming Law (1995) and other works.

China's legal and literary studies started relatively late. In the 1990s, Su Li translated a series of books by Posner to introduce "Law and Literature" to China, and then published the book Law and Literature: Traditional Chinese Drama (2006). In 1999, Feng Xiang of Hong Kong published the classic work of Law and Literature Wood Leg Justice. Around the 21 st century, there have been a number of high-quality academic works in mainland China, such as Xu Zhongming's Between Law and Literature (2000), He Weifang's Fa Bian Yu Mo(1998), Wang Shirong's Research on Ancient Chinese Verdicts(1997), etc.

2. Connection between Law and Literature

Law and literature, the two research areas, seem to be far away from each other. The law uses the force of law to restrain people's behavior. While literature uses emotional power to influence people's inner feelings, thus affecting people's thoughts and changing people's actions. In terms of its objectives, both are the pursuit of ideal social values such as freedom, fairness, justice, science, and rationality. They are all people's expectations for the good qualities of human beings such as truth, goodness and beauty. It's just that the two adopt different ways. The law restraints behavior but the literature influences behavior.

In fact, law and literature have a long and extensive connection. As early as in ancient Greece, the tragic work Antigone made people be aware of the huge conflict between law and morality through literature. Many literary masterpieces are also based on legal subjects, such as The Merchant of Venice, Hamlet, Crime and Punishment, Resurrection, Snow in Midsummer and so on. In addition, many writers have experience in studying law, such as Goethe, Tolstoy, Balzac, Voltaire, Xu Zhimo and so on. At the same time, literature also promotes the development of law with its characteristics. The law is recorded and disseminated by words. They are rigorous in structure and argumentation and fluent in language that is easy to understand. The law itself is a masterpiece of literature.

3. Introduction of "Law in literature"

Posner divided "Law and Literature" into four branches: Law in Literature, Law as Literature, Law through Literature and Law of Literature. "Law in literature" is the study of legal issues in the context of literary texts. It is the most important branch of the "Law and Literature" movement. And also it is the theoretical foundation adopted by this thesis.

The "Law in Literature" uses literary text as a sample or platform to explore the legal issues involved, which sets a 
"media" (literary work) between the researcher and the social reality. "Discovering the works" and "interpreting the works" have become the two links that the researchers must to go through. The study of "law in literature" has a positive effect on the promotion of the value of the law, the knowledge of popularization law, the improvement of law teaching, and the strengthening of legal rhetoric.(Wei, 2011)

\section{B. Research Object}

1. Introduction of Tomas Hardy and Tess of the d'Urbervilles

a. Introduction of Tomas Hardy

Thomas Hardy was one of Britain's greatest writers and poets in the late 19th and early 20th centuries. He published 18 novels and 8 episodes of 918 poems in his life. This made important contributions to English literature and even world literature. Hardy was born in Upper Berkhampton on the outskirts of Dorchester, Dorset. His novels had a strong local color because they were mostly based on the southwestern part of England where he lives. He focuses on the life of ordinary people so that the characters in his works are ordinary people in society who existed the weaknesses in human nature. Besides, his novels had a strong pessimistic color and a religious rebellious spirit. In summary, his novels mainly described the great changes in the British from the feudal society to the capitalist society from the late 19th century to the early 20th century, as well as the unfair society and law in this process and the tragic life of the peasants.(Xue, 2011)

b. Introduction of Tess of the d'Urbervilles

The Tess of the d'Urberville, published in 1891, is regarded as one of Hardy's masterpieces. It is a tragic work. Tess, the heroine of the novel, is a farm girl. She is not only beautiful, but also kind, sincere, hardworking and loving life. As she and her younger brother drove to the market at night, the old horse was killed by a mail truck, which caused the poor family to lose their financial resources. She had to listen to her mother to persuade her to work for the bogus kinsfolk. Unfortunately, she was raped by the young master of the landlord Alec and returned to her hometown with her pregnancy. After the child died, she went to a farm as a milker where she met the son of the pastor, Angel Clare, and fell in love with him. On the wedding night, the sincere Tess confessed to her husband Clare that she had lost her virginity. However, her husband couldn't take it. Clare left her and went to Brazil alone. Later, because of the death of his father, the family became homeless. Tess, who had nowhere to go, agreed to live with him under the entanglement of Alec. Unexpectedly, after a hardship, Clare finally changed his mind and came back from Brazil to look for Tess. Tess with remorse stabbed Alec to death. She spent a few days of happy life with her husband, Clare, and was finally arrested and sentenced to death. The tragedy of Tess is actually a social tragedy. Through the tragic experience of Tess and her family, this article truly depicts the tragic picture of individual agriculture going to poverty and bankruptcy after capitalism invaded the British countryside in the late 19th century. (Hardy, 2013)

2. Introduction of Lu Xun and The New-Year Sacrifice

a. Introduction of Lu Xun

As the founder of modern Chinese literature, Lu Xun has an important influence on the development of Chinese social ideology and culture after the May 4th Movement. He is famous in the world of literary circles, especially in the fields of Korea and Japan, and is known as "A writer who occupies the largest territory on the map of East Asian culture in the twentieth century". Lu Xun was born in a declining family of literati and officialdom. His grandfather was dismissed from prison because of imperial examinations, his family began to decline, and his family moved into rural life. In his 55 years of life, more than 10 million words have been passed down to the world. The types or forms of literature involves novels, essays, prose, poetry and so on. Among them, Lu Xun didn't write too many novels, but they are of great significance, mostly based on the life of the bottom people in the late Qing Dynasty and the early Republic of China. He paid attention to the details of the description which can vividly portray characters and explore subtle psychological changes. It mainly manifests the numbness and ignorance of the people's thoughts at the bottom and the hardships of life. After the founding of New China, his dozens of works were selected into Chinese textbooks for primary and secondary schools, which have far-reaching influence on the language and literature of New China.

b. Introduction of The New-Year Sacrifice

The New-Year Sacrifice written in 1924 is one of Lu Xun's novels during the Republic of China, and is the first of Lu Xun's second collection of novels Wandering. Xianglin's Wife is a tragic figure. She is a sincere and hardworking rural woman. After the husband's death, the cruel-hearted mother-in-law wanted to sell her. She was forced to flee and went to Lu family in Luzhen to be a servant.But she was taken away by her mother-in-law and took all her wages, and then sold her to He family as a wife. Resisting fruitlessly, Xianglin's Wife accepted the reality that lived with the simple and honest husband He Glen and gave birth to a son Amao. However, unfortunately, He Glen died of typhoid fever, and his son Amao was eaten by the wolf. Xianglin's Wife was driven out of the house by her husband's brother. She could only go to Lu family to work again. However, people felt that she is guilty of remarriage. She donated money to the Temple of the Tutelary God and still could not get rid of the discrimination against her. Finally, she begged along the street and desperately died on the streets. However, people not only did not pity her, but also thought that she was a bad lot. The life of Xianglin's Wife reflects the social contradictions after the Revolution of 1911 and the true face of the Chinese countryside. It profoundly reveals that the landlord class has devastated and persecuted the working people, especially the working women, and also discloses the innate character of eating human being under the feudal system to point out the necessity of thorough anti-feudalism. 


\section{Research Purpose}

Hardy (1840-1928) and Lu Xun (1881-1936), two literary giants, one lived in the English countryside in Dorset, and the other was born in a declining family of literati and officialdom in southern China. They were both familiar with rural life. They understood the hardships of the working people at the bottom and were very sympathetic to their oppressed situation. Tess and Xianglin's Wife were both the image of hardworking and simple women at the bottom of the society living in the same era. Moreover, they were both the tragic images of misfortunes. Through the research, there is no difficulty in finding that more and more scholars and professors begin to pay attention to the study of Hardy's and Lu Xun's works from interdisciplinary perspective. However, few studies have looked at their works from legal perspective. Besides, a lot of doubts also exist in understanding the predicament of women in the East and West in the late 19th and early 20th centuries. The author uses Hardy's Tess of the d'Urbervilles and Lu Xun's The New-Year Sacrifice as the research object to analyze the miserable fate of Tess and Xianglin's Wife from the perspective of the legal system through the theory of "Law in Literature". This paper intends to compare the legal system of the British Victorian and Chinese semi-colonial and semi-feudal periods and reveal the predicament of the survival the women in the East and West around the 20th century.

\section{LAW IN TESS OF D'URBERVILLES ——MisERABLE FATE OF TESS}

\section{A. Property and Surname}

The economic distress caused Tess to compromise the reality again and again against her own will. Although the family of d'Urbervilles had been glorious for centuries, the generation of Tess has been declining. Tess accidentally killed a horse that his father used to do business, which made the whole family into an economic dilemma. In desperation, she had no choice but to work in the Stoke-d'Urbervilles family so as to solve her family's livelihood problem, which then triggered subsequent tragedies. It can be learned from the novel that her family was originally prestigious. The real estate of the Stoke family (the house of hennery of Alec's mother) was originally the legacy of the d'Urbervilles family. To explore the question why it was inherited by Stoke family, the best way is to understand the legal background at that time.

The English Law of Succession stipulates that as long as there is a heir (whether male or female, whether direct relative or collateral relatives) existed, the land given by the lord can be inherited indefinitely. In practice, this inheritance relationship extended from 1066 to the early 20th century.(Xue, 2011) The novel mentions that their family consisted of numerous branches and once had a large amount of land.(Hardy, 2011)According to English law, this property can be inherited unconditionally as long as it is a legally recognized descendant of d'Urbervilles family.

As a descendant, the reason that Tess's grandfather didn't have the right of inheritance is the deep development of British capitalism in $19^{\text {th }}$ century. In order to complete the bourgeois revolution, the British authorities disintegrated the feudal land ownership system and defeated the feudal aristocracy. The British abolished Corn Laws and established the Inheritance Tax Law to open up the domestic grain market. The influx of high-quality and cheap grain from abroad into the UK shocked the British agriculture and hit the feudal aristocrats whose feudal manor rent was the main income, which drastically reduced their income.(Yan, 2006) In this way, the feudal aristocrats who were unable to pay taxes had to sell or shelve the property that cannot be inherited. (Yan, 2006)

After the timber merchant Simon Stoke accidentally made a fortune, he occupied the surname of d'Urbervilles. Although the change of surname would not bring him the same political aristocratic status, it provided the legal conditions necessary to invade the d'Urbervilles family heritage. At that time, the inheritance law stipulated, in addition to paying the inheritance tax, it is necessary to prove the identity by a legally recognized document or a family seal, otherwise it cannot be inherited, or cannot obtain ownership even if occupied. However, the phenomenon of illegal possession of feudal aristocratic real estate by emerging assets was very common at that time. In order to legalize it, the bourgeois-controlled parliament promulgated the Land Transfer Law in 1875, despite the opposition of the original feudal aristocracy. The act stipulates that the parties register the property rights on a voluntary basis, and the registered property rights have the effect of the counter-prescription system. The level does not require substantive examination. (Xian, 2009) The law of the age caused the Tess family to lose their home and fell to the bottom of society.

\section{B. Forced Sex and Pregnancy}

It is a significant turning point that Tess lost her virginity in the novel. For the reason that Hardy was vague in describing this event, it did not determine the nature. There has always been a different analysis and interpretation of the nature of the event. However, it can be inferred from some clues in the novel. From the novel, Alec coveted Tess' beauty for a long time, but Tess has always maintained an attitude of avoidance and disgust. On the day of the incident, She was so tired after her long day. However, she was humiliated on the way back from the weekly pilgrimage. In such a case, she accepted Eric's proposal and scrambled into the saddle behind Alec, and left with him. Then Alec and Tess' dialogue also reflect Tess' avoidance of Alec. "Tess, why do you always dislike my kissing you?" "I suppose because I don't love you." (Hardy, 2011, p.83)When she was overcome by drowsiness, she also kept a guard against Alec's touch on her. Thus, Tess and Alec did not have an emotional foundation. Next, Alec deliberately let the horse walk through the oldest woods and got lost. When he was looking for a way out alone, Tess fell asleep because she was 
too tired. She slept so soundly that she did not answer Alec's call. "D'Urberville stooped; and heard a gentle regular breathing. He knelt and bent lower, till her breath warmed his face, and in a moment his cheek was in contact with hers. She was sleeping soundly."(Hardy, 2011, p.88)This section of the description proves that Tess had a sexual relationship with Alec while asleep.

The Victorian English law clearly states that "rape is a crime of sexual violence against women and sexual intercourse against women's will." (Wu, 2009, p.79)John Mews clearly stated in the The Digest English Case Law that sexual relationships are enough to characterize rape as long as the woman's consent is not obtained. And there are legal provisions that specifically state that if a man has sex with a woman while she is asleep, rape is formed even without violence.(Wu, 2009) Compared with Tess' previous behavior, if she was not asleep, she was bound to resist.

If Tess was raped and it was a great injury to her body and mind, then child out of wedlock gave her a greater disaster. From the description in the novel, it was found that Tess had a contradictory feeling of both hatred and love for this undesired child.(Hardy, 2011)The child destroyed the reputation of Tess and her family and made her life even more tragic. Since Tess has no feelings for Alec, the question why she gave birth to his child after leaving Alec is worth discussing

It was all due to the laws of the time. According to the section 58 of Offences Against the Person Act 1861, abortion by unlawfully administration any poison or noxious thing is an offence. It is sentenced to life imprisonment.(Smith\&Hogan, 2011)Under such laws, Tess had to give birth to this child and exposed the fact that she lost her virginity, and she had to go to the dairy-house many miles to the southward to be a milkmaid.

\section{Unhappy Marriage}

On the wedding night, Tess couldn't stand the inner suffering, so she confessed to the past experience to Angel and hoped to get his forgiveness. But Angel could not forgive her. Tess wanted to relieve Angel's pain through divorce, but Angel said that he could not divorce Tess. "You don't understand the law - you don't understand."(Hardy, 2011) How was the law at that time prescribed?

The marriage and divorce of the British have always been approved by the church court. In the eyes of Christians who believe in religion, the union of men and women is God's will. Divorce is not allowed. It was not until 1857 that things improved. The law allowed people to divorce through the judgments of the courts, but it had strict legal conditions. A husband could divorce his wife on the ground of adultery, and a wife must prove the additional offense such as desertion, cruelty, rape, or incest before the divorce. (Jenks, 2002) Under this law, Tess and Angel could not be free through divorce, so Angel could only leave Tess alone to go to Brazil.

\section{Death of Loved One}

After Clare left, Tess barely maintained her life by working. But her father died made the family once again get into trouble. The British land tenure system is divided into three types that is freehold tenure, copyhold tenure and leasehold tenure. The family of Tess belonged to the leasehold tenure. After the father's death, the lease contract was automatically terminated. The mother of Tess, as the spouse, could not have any rights according to the contract. Tess family had no choice but lived in the ancestral cemetery. However, Vagrancy Act 1824 stipulates it as a crime.

"every person wandering abroad and lodging in any barn or outhouse, or in any deserted or unoccupied building, or in the open air, or under a tent, or in any cart or waggon, not having any visible means of subsistence, and not giving a good account of himself or herself; every person being found in or upon any dwelling house, warehouse, coach house, stable, or outhouse, or in any inclosed yard, garden, or area, for any unlawful purpose; every suspected person or reputed thief, frequenting any river, canal, or navigable stream, dock, or basin, or any quay, wharf, or warehouse near or adjoining thereto, or any street, highway, or avenue leading thereto, or any place, of public resort, or any avenue leading thereto, or any street, highway, or place adjacent, with intent to commit felony; shall be deemed a rogue and vagabond"(Xie, 2003)

Desperately, Tess had no choice but become mistress of Alec again. From then on, her life is full of sadness. And she broke out when Angle tried to save their marriage. Finally, Tess was killed by the murder of Alec.

\section{LAW IN THE NEW-YEAR SACRIFICE-MiseRABLE FATE OF XiANGLIN’S WifE}

\section{A. Surname and Property}

When the full text was introduced to her, she was named Xianglin's Wife. There is no mention of her autonym so we cannot know her real name. And in the novel, her mother-in-law took all her wage easily. From these two points, it is easy to learn Xianglin's Wife had no status or rights both in society and her husband's family.

After the Opium War, China became a semi-colonial and semi-feudal society. During this period, feudalism still existed. The feudal system has existed in China for more than 2,000 years. It reflected that the feudal ideology of the feudal ruling class has penetrated into the customs and habits of the Chinese. So the influence of this tradition in China is deeply rooted. In the paternal family order of the laws and folk customs of the Qing Dynasty, women were regarded as the vassals of men in their will and status. 《礼记・内则》谓“子子妇无私货, 无私畜, 无私器; 不敢私假, 不敢私与。” (Ding, 2011, p.78)That implies that the woman has no property before and after marriage and even the dowry she brings from her mother's home is deprived. 
The new ideological trend brought by the invasion of foreign powers also impacted Chinese society. In terms of law, compared with the laws of the Qing dynasty, the laws of the National Party abandoned hierarchical relations and advocated equality before the law. The $1135^{\text {th }}$ draft of the Civil National Draft Law stipulates “妻于成婚时所有之财 产及婚后所得之财产，为其特有财产。但就其财产，夫有使用、收益之权。”.(Yang et al, 2002, p.355 )It means that the property owned and acquired by the wife before and after marriage is her exclusive property. However, the husband has the right to use and profit from his wife's property. At the legal level, woman's interests were protected.

\section{B. Unhappy Marriage}

Xianglin's Wife's first husband, a woodcutter, was ten years younger than she was.(Yang, 2010) It can be inferred that she is a child bride. And her mother-in-law was "a clever, capable woman, a fine manager".(Yang, 2010, p.17) Concluded from the two perspectives, Xianglin's Wife had no position in the husband's family.

Child bride, a common phenomenon in the Qing Dynasty, is the baby girl or young girl fostered by her husband's family until the formal marriage in adulthood. The child brides are very young, and even some are also staying at the family to wait for the young son-in-law to become an adult although they have reached the legal age of marriage in the Qing Dynasty. The reason why the children are raised is the society at that time was very poor and backward, and the living standard of the people was very low. The custom was not codified in the Qing Dynasty, but law-executor recognized and tolerated it, which made it legal.(Huang, 2007) Child bride is generally older than the husband so that she can take care of the husband. Although the marriage of child bride is not necessarily the result of mercenary marriage, there still be a serious relationship between mother-in-law and daughter-in-law. The status of daughter-in-law is generally low, especially in mercenary marriage. They have to do a lot of housework, and some are abused by their husband's family and servants. In the novel, the description of Xianglin's Wife's work in Lu Family used the phrase "got through more work than a hard-working man".(Yang, 2010, p.13) And her clever and capable mother-in-law wanted to sell her after her husband's death. To sum up, their relationship was not harmonious and the position of Xianglin's Wife at home was very low.

In the National Party code, the existence of child bride was illegal but there was a big gap between the law and the real situation of women at that time.(Huang, 207)

\section{Forced Sex and Pregnancy}

Unfortunately for the death of Xianglin's Wife's husband, her mother-in-law did not allow her to keep her chastity. She wanted to sell Xianglin's Wife, and use the money earned as bride price to get a wife for her second son. Although Xianglin's Wife ran away to fight her fate but finally was forced to marry to He(surname) family and gave birth to the son Amao.

In the old days, women were the vassals of men in their status and will. Women are part of the husband's property and have no independent personality rights. When the family is unable to save themselves, the husband and his family can take advantage of wife by divorcing and selling for a profit. The sale of wives for marriage or prostitution, the forcing of widows to remarry, the purchase as little girls for child brides were widespread phenomena in the 18th and 19th centuries.(Huang, 2007) In the peasant society of the Qing dynasty, once a woman's husband died, she was vulnerable to aggression by her in-laws, especially if she was childless or young and beautiful for the reason that she can be sold with good price. If a widow was helpless and returned to her mother's home, she would be under great pressure to remarry for the bride price she would bring. The law of the Qing dynasty favored widows who dared to resist these pressures and praised their chastity. And it was illegal for their husband's family or their mother's family to force them to remarry against their will. Once they violated, they would have bludgeoned for 80 times.(Huang, 2007) However, although this phenomenon was forbidden by the law code, the judiciary in the Qing dynasty tolerated it out of sympathy for the poor. The unfortunate or abused wives had no choice but to run away from home.(Huang, 2007)

The $1345^{\text {th }}$ draft of the Civil Law Draft of Qing Dynasty stipulates that “因许欺或胁迫而婚姻者, 惟当事人得撤销 之。以六个月为限”. (Yang et al, 2002, p.172) If the marriage is fraudulent and coerced, it is revoked only by the party within six months. But obviously, due to the ignorance and ineffectiveness of the law, woman's right could not be guaranteed in that chaotic period.

\section{Death of Loved One}

It can be said that the death of husband He Glen and her son Amao pushed Xianglin's Wife who had regained happiness to be more despaired. To add to her misery, her husband's elder brother kicked her out by taking over the house.

In fact, from the $1467^{\text {th }}$ draft of the Civil Law Draft of Qing Dynasty “妇人夫亡无子守志者, 得承其夫应继之分, 为继承人”,(Yang et al., 2002, p.188) it can be found that if a woman's husband dies and has no children, she will inherit her husband's inheritance and be his successor. Therefore, in law, Xianglin's Wife had the right to continue to live in her husband's house, but she did not fight for her right.

From then on, her life descended into tragedy and she died in despair because of people's rumors and scorn.

\section{The Survival Plight of Women}


From the legal events and legal acts in Thomas Hardy's Tess of the d'Urbervilles and Lu Xun's The New-Year Sacrifice, it is not difficult to conclude that there are many difficulties in the lives of women in the East and West around the 20th century. Below, the deficiencies of woman's living conditions are explained from the legal perspective.

\section{A. Ineffectiveness of the Law}

From the analysis of Tess and Xianglin's Wife, it can be found that although the law intends to protect the status and rights of women, it was not implemented in the actual reality, which reflects the ineffectiveness of the law. The paper tries to demonstrate the ineffectiveness of the law from following two aspects of the limitations of social context and cognition.

1. The Limitations of Social Context

a. Ideological Confusion in Victorian

For the Westerners, the 19th century was a century of extremely chaotic thoughts and a century in which traditional values were disintegrated. The emergence of the second industrial revolution brought new ideas to the world. The new ideas put forward by outstanding people such as Nietzsche, Darwin and Schopenhauer have brought great impact to the traditional values of westerners. The ideology of Victoria was vibrant in the context of moral chaos and the alternation of old and new cultures.

b. Ideological Confusion in Semi-colonial and Semi-feudal Society

After the opium war, China was reduced to a semi-colonial and semi-feudal society. At that time, the feudal ideology of more than 2,000 years was impacted, and western ideas were gradually introduced into China. China sought its own new thoughts and cultures in this context of the thoughts and cultures of various countries collided and merged. There is no doubt that China was in a time of ideological chaos.

2. The Limitations of Cognition

In the British Victorian and Chinese semi-colonial and semi-feudal society, the attention to the status of women had gradually increased. But in general, woman's education level was generally not high especially in rural areas, while Tess and Xianglin's Wife are the image of the rural woman. In this context, woman's cognition of the law had limitations that prevented them from maintaining their interests in a timely and effective manner.

\section{B. Injustice of the Law}

The law is the product of the state. It refers to the basic laws and common laws promulgated by the ruling class after certain legislative procedures for the purpose of realizing the rule and managing the state. The law is the embodiment of the will of the entire nation and the instrument of state rule. Therefore, the bias of justice of the law depends on the needs of the ruler to govern the country. Moreover, due to the low social status of women, the protection of woman's rights and interests by the law is far from enough. This is also the embodiment of the law's injustice to women.

\section{Imperfection of the Law}

The lag of law determines that the law can never be perfected. Since the development of human science and technology culture is changing with each passing day, the law always has to solve the problems that arise. When the previous problems are solved, new problems will arise. The revision of the law is to constantly improve the differences between the legal system and ideas. Similarly, there were such problems in society at the time.

\section{CONCLUSION}

Through analyzing the experiences of Tess and Xianglin's Wife, this paper has a deeper understanding of the social reality of woman's life in British Victorian and Chinese semi-feudal and semi-colonial society. This paper tries to study in the field of literature and law from the standpoint of literature, and uses the legal perspective to reinterpret the exact meaning of legal events involved in the works of Tess of the d'Urbervilles and The New-Years Sacrifice. This helps us analyze the cause of protagonist Tess and Xianglin's Wife's tragic ending. Besides, it provides an important reference for us to understand the legal and judicial systems of the British Victorian and Chinese semi-colonial and semi-feudal society. It plays an important role in understanding the living environment of women and exploring the predicament of woman's survival in the East and West at that time. This also reflects the authors' critical attitude towards the law at that time. The paper concludes that the limitations of social background and cognition, as well as the injustices and imperfections of the law, lead to the predicament of woman's survival. However, as not a professional law learner, this paper still has some deficiencies in the study and translation of legal regulations. To sum up, although we can't solve some deficiencies in the law, we should use the legal means to protect our own rights and interests.

\section{REFERENCES}

[1] Ding,H.B. (2011). Anthropological reflection and Cultural Critique in Lu Xun's Novels. Northeast Normal University

[2] Hardy,T. (2011). Tess of the d'Urbervilles. Beijing: China International Broadcasting Publishing House.

[3] Hardy,T. (2013). Tess of the d'Urbervilles. Beijing: Foreign Language Teaching and Research Press.

[4] Huang,Z.Z. (2007). Code, Custom and Judicial Practice:A comparison between Qing Dynasty and the Republic of China. Shanghai: Shanghai Bookstore Publishing House.

[5] Jenks,E. (2007). The Book of English Law. Beijing: China University of Political Science and Law Press. 
[6] Ponser,R.A. (1987). The Decline of Law as an autonomous Discipline: 1962-1987. 100 Harvard Law Review 761-780.

[7] Smith,J.C \&Hogan, B: Criminal Law. Beijing: Law Press China.

[8] Wei,J.M. (2011). "Law in Literature" and Its Roles. Science Economy Society (vol.2), 133-136.

[9] Wu,D. (2009). New studies in Tomas Hardy. Hangzhou: Zhejiang University Press.

[10] Xiang,H.C. (2009). English Land Law History-An Investigation from the Perspective of Tenure. Beijing: Peking University Press.

[11] Xie, W.Y. (2003). Selections From English Criminal Statutes From 1351 To 1997. Beijing: People’s Public Security University of China Press.

[12] Xue,Q. (2011). Criticism on Cause of Tess of the D'Urbervilles's Tragedy the Legal Perspective. Zhejiang University.

[13] Yan,Z.X. (2006). Research on Modern British Aristocracy System. Beijing: People's Literature Publishing House.

[14] Yang,L.X. (2002). Civil Law Draft of Qing Dynasty\& Civil National Draft Law. Jilin: Jilin People's Publishing House.

[15] Yang,X.Y et al. (2010). Wandering. Beijing: Foreign Language Press.

Haiting Chen was born in Zhejiang, China in 1998. She is currently a college student in Zhejiang Ocean University, Zhoushan, China. Her research interests include law and literature.

Jingjing Lu is an associate professor in Foreign Language College, Zhejiang Ocean University, Zhoushan, China. She received her M.A. degree in linguistics and applied linguistics from Huazhong University of Science and Technology, China in 2006. Her research interests include cross-culture communication, English teaching and discourse analysis. 